\title{
PENAMPILAN PADI GOGO PADA SISTEM TANAM PADI-RUMPUT DENGAN APLIKASI ASAP CAIR TEMPURUNG KELAPA PADA KONDISI KEKERINGAN
}

\section{UPLAND RICE PERFORMANCE IN RICE-GRASS INTERCROPPED WITH APPLICATION OF COCONUT SHELL WOOD VINEGAR UNDER DROUGHT}

\author{
Yugi R. Ahadiyat ${ }^{1 *}$, Okti Herliana ${ }^{1}$, Ida Widiyawati ${ }^{1}$, Aprian Aji Santoso ${ }^{2}$ \\ ${ }^{1}$ Laboratorium Agroekologi, Fakultas Pertanian, Universitas Jenderal Soedirman \\ Jl. Dr. Soeparno Karangwangkal Purwokerto 53123 \\ ${ }^{2}$ Balai Penelitian Lingkungan Pertanian, Kementerian Pertanian \\ Jl. Raya Jakenan, Jaken km 5, Sidomukti, Pati 59182 \\ Korespondensi : ahadiyat.yugi@unsoed.ac.id
}

Diterima: 14 Oktober 2019/Disetujui: 29 Desember 2019

\begin{abstract}
ABSTRAK
Peningkatan produksi padi lahan kering dapat dilakukan dengan sistem tumpang sari dan pemanfaatan asap cair tempurung kelapa. Penelitian ini bertujuan untuk mengetahui pengaruh tumpangsari padi gogo-rumput dengan aplikasi asap cair tempurung kelapa terhadap karakter pertumbuhan, fisiologis, dan hasil padi gogo serta tingkat serangan hama dan patogen pada kondisi kekeringan. Penelitian menggunakan rancangan petak petak terbagi dengan tiga ulangan. Petak utama terdiri atas varietas padi gogo; Situ Bagendit, Inpago Unsoed 1 dan Situ Patenggang. Anak petak merupakan konsentrasi asap cair tempurung kelapa yaitu tanpa aplikasi, konsentrasi 1:100 dan konsentrasi 1:200. Anak-anak petak terdiri atas tanpa rumput, rumput gajah, sereh dan rumput gajah+sereh. Variabel yang diamati meliputi tinggi tanaman, jumlah dan luas daun, jumlah anakan, kandungan prolin, kadar klorofil a dan $b$, jumlah gabah isi, bobot gabah petak efektif, bobot gabah ha $^{-1}$, indeks panen, serta intensitas serangan hama dan patogen. Hasil menunjukkan bahwa padi gogo yang ditanam pada kondisi kekeringan dengan penanaman rumput dan aplikasi asap cair tempurung kelapa belum mampu menghasilkan produksi yang optimal. Tumpangsari padi gogo-sereh lebih memberikan dampak terhadap karakter pertumbuhan dan hasil padi gogo dibandingkan dengan aplikasi asap cair tempurung kelapa. Secara umum, hasil padi gogo $<1 \mathrm{t} \mathrm{ha}{ }^{-1}$, namun varietas Situ Patenggang menunjukan hasil lebih baik dibandingkan varietas lainnya. Intensitas serangan walang sangit lebih rendah pada sistem tumpangsari padi gogo varietas Situ Patenggang-sereh.
\end{abstract}

Kata kunci: Asap cair tempurung kelapa, kekeringan, padi gogo, rumput.

\begin{abstract}
Rice production in the upland can be increased by multiple cropping system and coconut shell wood vinegar application. The objectives of this study was to know the effects of

Cite this as: Ahadiyat, Y. R., Herliana, O., Widiyawati, I., \& Santoso, A.A. (2019). Karakter padi gogo pada sistem tanam padi-rumput dengan aplikasi asap cair tempurung kelapa pada kondisi kekeringan. Jurnal Agro, 6(2), 168-180 https://doi.org/10.15575/6134
\end{abstract}


intercropped rice-grass with application of coconut shell wood vinegar on characters of growth, physiological, and yield of upland rice as well as intensity of pest and disease under drought condition. Split split plot design with main plot of upland rice varieties i.e. Situ Bagendit, Inpago Unsoed 1 and Situ Patenggang, sub plot consist of coconut shell wood vinegar concentration i.e. 0, 1:100 and 1:200, sub sub-plot of rice-grass intercropped i.e. no grass, Pennisetum purpureum, lemongrass and Pennisetum purpureum+lemongrass were tested with three replications. Observed variables were plant height, leaf number, leaf area, number of tillers, contents of proline, chlorophyll a and b, weight of grain in effective plot, weight of grain ha-1, harvest index and intensity of pest and disease. The results showed that rice-grass intercropped and application of coconut shell wood vinegar in drought condition has not been able to produce the optimal production. Under drought condition, intercropped ricegrass had significantly impact on the character of growth and yield of the upland rice. Generally, all upland rice varieties gained low yield $\left(<1 \mathrm{t} \mathrm{ha}^{-1}\right)$, but Situ Patenggang variety showed higher yield than other varieties and low intensity of brownhopper attack as well as in rice-lemongrass intercropped.

Key words : coconut shell wood vinegar, drought, grass, upland rice.

\section{PENDAHULUAN}

Pemenuhan kebutuhan pangan nasional selama ini ditunjang oleh padi sawah irigasi (Nazirah \& Damanik, 2015). Menurut Badan Pusat Statistik (2016), kontribusi padi sawah yakni $95,2 \%$ dan $4,8 \%$ oleh padi gogo dari produksi padi nasional. Rendahnya kontribusi padi gogo memicu peningkatan produksi pangan di lahan kering. Menurut Murtilaksono \& Anwar (2014), ada sekitar 7,08 juta hektar dari 70,41 juta hektar lahan sub-optimal yang sesuai untuk pengembangan pertanian lahan kering tanaman semusim seperti padi gogo.

Potensi lahan kering di Indonesia untuk pengembangan pertanian masih sangat luas lebih dari 70 juta ha (Mulyani \& Sarwani, 2013; Murtilaksono \& Anwar, 2014). Adanya alih fungsi lahan, menurut Pusat Data dan Informasi Pertanian (2017) saat ini luas lahan kering untuk pengembangan pertanian menjadi sekitar 28 juta ha. Namun demikian, luas lahan kering yang potensial tersebut belum dimanfaatkan secara optimal untuk pengembangan tanaman padi dan tanaman pangan lainnya. Menurut Abdurachman et al. (2008), hal ini mungkin karena ada anggapan bahwa meningkatkan produksi padi sawah lebih mudah dan lebih menjanjikan dibanding padi gogo yang memiliki risiko kegagalan lebih tinggi. Oleh karena itu, untuk meningkatkan produksi padi khususnya di lahan kering dalam mendukung produksi padi nasional, perlu pengembangan pengelolaan budidaya padi gogo.Salah satu strategi yang dapat dilakukan untuk pengembangan budidya padi gogo yakni dengan sistem tumpangsari.

Keuntungan sistem tumpangsari selain diperoleh frekuensi panen lebih dari satu kali dalam setahun, juga berfungsi untuk menjaga kesuburan tanah (Prasetyo et al., 2009). Tumpangsari menjaga produksi tetap stabil dan memperbaiki kesuburan tanah (Wahla et al., 2009). Ahadiyat et al. (2013) melaporkan bahwa, sistem tumpangsari padi gogo-rumput gajah mampu memberikan hasil padi gogo tertinggi dibanding monokultur dan tumpangsari dengan sereh.

Pemanfaatan bahan lain untuk meningkatkan produksi padi gogo juga dapat dilakukan selain dengan sistem 
tumpangsari. Salah satunya dengan asap cair tempurung kelapa. Asap cair tempurung kelapa memiliki potensi sebagai bio-pestisida (Basri, 2010; Payamara, 2011) dan hormon atau pemicu pertumbuhan tanaman (Basri, 2010; Payamara, 2011; Muhakka et al., 2013). Namun demikian, penelitian asap cair tempurung kelapa yang diaplikasikan pada tanaman padi masih sangat terbatas.

Penelitian ini bertujuan untuk mengetahui pengaruh sistem tumpangsari jpadi dengan rumput gajah, sereh dan rumput gajah+sereh dengan aplikasi asap cair tempurung kelapa terhadap karakter pertumbuhan, fisiologis dan hasil tiga varietas padi gogo, serta tingkat serangan hama dan patogen pada kondisi kekeringan.

\section{METODE PENELITIAN}

Penelitian dilaksanakan di lahan percobaan di Desa Cendana, Kecamatan Kutasari, Kabupaten Purbalingga pada ketinggian tempat $360 \mathrm{~m}$ dpl. Penelitian dimulai bulan April sampai Agustus 2016. Selama penelitian intensitas curah hujan sangat rendah kurang dari $80 \mathrm{~mm}$ bulan $^{-1}$.

Bahan utama dari penelitian ini adalah tiga varietas padi gogo, yaitu Inpago Unsoed I, Situ Patenggang, dan Situ Bagendit. Selain itu, juga digunakan rumput gajah, sereh, dan asap cair tempurung kelapa grade 3 . Penelitian ini menggunakan rancangan perlakuan petak petak terbagi dalam rancangan acak kelompok lengkap (RAKL) dengan 3 ulangan. Petak utama merupakan varietas padi gogo, yaitu Situ Bagendit, Inpago Unsoed 1 dan Situ Patenggang. Anak petak merupakan konsentrasi asap cair tempurung kelapa, yaitu tanpa asap cair tempurung kelapa, konsentrasi 1:100 (18 ml $\mathrm{L}^{-1}$ atau $30 \mathrm{~L} \mathrm{ha}^{-1}$ ) dan konsentrasi 1:200 (9 $\mathrm{ml} \mathrm{L}^{-1}$ atau $15 \mathrm{~L} \quad \mathrm{ha}^{-1}$ ), Anak-anak petak yaitu penanaman padi gogo tanpa rumput, padi gogo-rumput gajah, padi gogo-sereh dan padi gogo-rumput gajah+sereh. Setiap perlakuan diulang tiga kali, sehingga terdapat 9 petak utama, 27 anak petak, dan 108 anak-anak petak. Asap cair tempurung kelapa diaplikasikan seminggu sekali dengan disemprotkan ke daun padi sejak tanaman berumur 14 hari setelah tanam. Pemangkasan terhadap rumput gajah dan sereh dilakukan sesuai kebutuhan untuk menghindari penutupan ke tajuk tanaman padi. Padi ditanam dengan jarak tanam $25 \times 25 \mathrm{~cm}$ pada petak percobaan $2 \times 4 \mathrm{~m}$. untuk rumput ditanam dengan jarak tanam $25 \times 75 \mathrm{~cm}$ diantara tanaman padi sehingga terdapat 42 lubang tanam untuk rumput gajah, sereh dan rumput+gajah sereh sesuai perlakuan pada setiap petak percobaan.

Variabel pada tanaman padi yang diamati meliputi: tinggi tanaman, jumlah daun, luas daun, jumlah anakan, kandungan prolin, kadar klorofil a dan b, jumlah malai, panjang malai, jumlah gabah isi dan hampa rumpun $^{-1}$, bobot gabah isi rumpun ${ }^{-1}$, bobot gabah 1000 biji, bobot gabah petak efektif ${ }^{-1}$ $(2,5 \times 1,5 \mathrm{~m})$, bobot gabah $\mathrm{ha}^{-1}$, indeks panen, serta tingkat serangan hama dan patogen.

Data hasil pengamatan dianalisis menggunakan uji $\mathrm{F}$ untuk mengetahui tingkat signifikansi masing-masing faktor perlakuan dan interaksinya terhadap variabel yang diamati dengan menggunakan software DSAASTAT 1.101. Apabila terdapat perbedaan yang nyata pada hasil uji $\mathrm{F}$ akan dilanjutkan dengan uji Beda Nyata Terkecil $(p=0.05)$.

\section{HASIL DAN PEMBAHASAN}


Karakter pertumbuhan dan fisiologis varietas padi gogo menunjukan respons yang beragam pada sistem tumpangsari padi-rumput dengan aplikasi asap cair tempurung kelapa. Semua perlakuan menunjukan hasil yang berbeda nyata secara mandiri terhadap tinggi tanaman, sedangkan jumlah daun hanya dipengaruhi oleh penanaman rumput saja (Tabel 1). Keberadaan rumput pada beberapa varietas menunjukan hasil yang berbeda nyata terhadap jumlah anakan dan kadar klorofil b (Tabel 1). Kadar klorofil a dan prolin menunjukan hasil yang tidak berbeda nyata (Tabel 1). Selain pengaruh mandiri dari setiap perlakuan, terdapat interaksi antara varietas dan rumput terhadap tinggi tanaman dan kadar klorofil b (Tabel 1) serta interaksi semua perlakuan tehadap luas daun (Gambar 1).

Tinggi tanaman dan jumlah anakan tinggi dihasilkan oleh varietas Inpago Unsoed 1 dan Situ Patenggang serta saat ditanam tumpangsari dengan sereh (Tabel 1). Aplikasi asap cair tempurung kelapa belum mampu meningkatkan karakter pertumbuhan dan fisiologis tanaman kecuali terhadap tinggi tanaman pada konsentrasi 1:100 (Tabel 1). Karakter jumlah daun pun mampu menghasilkan jumlah yang tinggi saat ditanam tumpangsari dengan sereh. Tumpangsari padi-rumput dengan aplikasi asap cair tempurung kelapa belum mampu meningkatkan kadar klorofil a dan prolin pada semua varietas yang diuji (Tabel 1 ).

Tabel 1. Karakter Pertumbuhan dan fisiologis varietas padi gogo pada tumpangsari padi rumput dengan aplikasi asap cair tempurung kelapa

\begin{tabular}{|c|c|c|c|c|c|c|}
\hline \multirow[b]{2}{*}{ Perlakuan } & \multicolumn{3}{|c|}{ Pertumbuhan } & \multicolumn{3}{|c|}{ Fisiologis } \\
\hline & $\begin{array}{l}\mathrm{TT} \\
(\mathrm{cm})\end{array}$ & $\begin{array}{c}\mathrm{JD} \\
\text { (helai) }\end{array}$ & $\begin{array}{c}\text { JA } \\
\text { (batang) }\end{array}$ & $\begin{array}{c}\text { Klorofil a } \\
\left(\mathrm{mg} \mathrm{g}^{-1}\right)\end{array}$ & $\begin{array}{l}\text { Klorofil b } \\
\left(\mathrm{mg} \mathrm{g}^{-1}\right)\end{array}$ & $\begin{array}{c}\text { Prolin } \\
\left(\mu \mathrm{mol} \mathrm{g}^{-1}\right)\end{array}$ \\
\hline \multicolumn{7}{|l|}{ Varietas } \\
\hline Situ Bagendit & $55,3 a$ & 23,1 & $16,6 a$ & 0,022 & $0,079 a$ & 14,696 \\
\hline Inpago Unsoed I & $73,9 b$ & 25,0 & $19,5 b$ & 0,024 & $0,099 b$ & 14,245 \\
\hline Situ Patenggang & $75,8 b$ & 27,3 & $18,3 b$ & 0,022 & $0,099 b$ & 11,665 \\
\hline KK (\%) & 21,64 & 20,39 & 18,39 & 13,32 & 18,86 & 13,90 \\
\hline \multicolumn{7}{|l|}{$\begin{array}{l}\text { Konsentrasi Asap } \\
\text { Cair Tempurung Kelapa }\end{array}$} \\
\hline 0 (Tanpa aplikasi) & $65,4 a$ & 25,3 & 17,8 & 0,023 & 0,089 & 14,482 \\
\hline $1: 100$ & $72,3 b$ & 23,5 & 19,3 & 0,022 & 0,096 & 14,505 \\
\hline $1: 200$ & $67,4 a$ & 24,7 & 18,2 & 0,023 & 0,092 & 11,614 \\
\hline KK (\%) & 12,97 & 12,47 & 21,51 & 18,14 & 19,32 & 12,30 \\
\hline \multicolumn{7}{|c|}{ Tumpangsari padi-rumput } \\
\hline Tanpa Rumput & $68,3 b$ & $26,6 b$ & $18,4 \mathrm{c}$ & 0,024 & $0,085 a$ & 11,591 \\
\hline Rumput Gajah & $66,5 a$ & $21,3 a$ & $17,2 a$ & 0,023 & $0,086 a$ & 14,153 \\
\hline Sereh & $70,5 c$ & $28,4 \mathrm{c}$ & $19,2 d$ & 0,023 & $0,093 a$ & 13,670 \\
\hline Rumput Gajah+Sereh & $68,1 b$ & $21,6 a$ & $17,7 b$ & 0,022 & $0,106 b$ & 14,720 \\
\hline KK (\%) & 6,77 & 12,76 & 14,81 & 11,73 & 15,34 & 14,48 \\
\hline
\end{tabular}


Tumpangsari padi varietas Situ Patenggang dengan sereh menghasilkan tinggi tanaman tertinggi dan secara umum keberadaan rumput mampu menghasilkan tinggi tanaman yang tinggi pada semua varietas padi gogo yang diuji Gambar 1 . Antar varietas yang ditanam tumpangsari padi-rumput dengan aplikasi asap cair tempurung kelapa menunjukan respons yang beragam. Inpago Unsoed 1 yang ditanam dengan sereh tanpa ataupun dengan aplikasi asap cair tempurung kelapa mampu menghasilkan luas daun tinggi. Varietas Situ Patenggang mampu menghasilkan luas daun tinggi apabila ditanam tanpa rumput dengan aplikasi asap cair tempurung kelapa 1:100. Untuk varietas Situ Bagendit yang ditanam tumpangsari padi-rumput dengan tanpa ataupun diberi asap cair tempurung kelapa menghasilkan luas daun yang lebih rendah dibandingkan dengan varietas Inpago Unsoed 1 dan Situ Patenggang (Tabel 2).

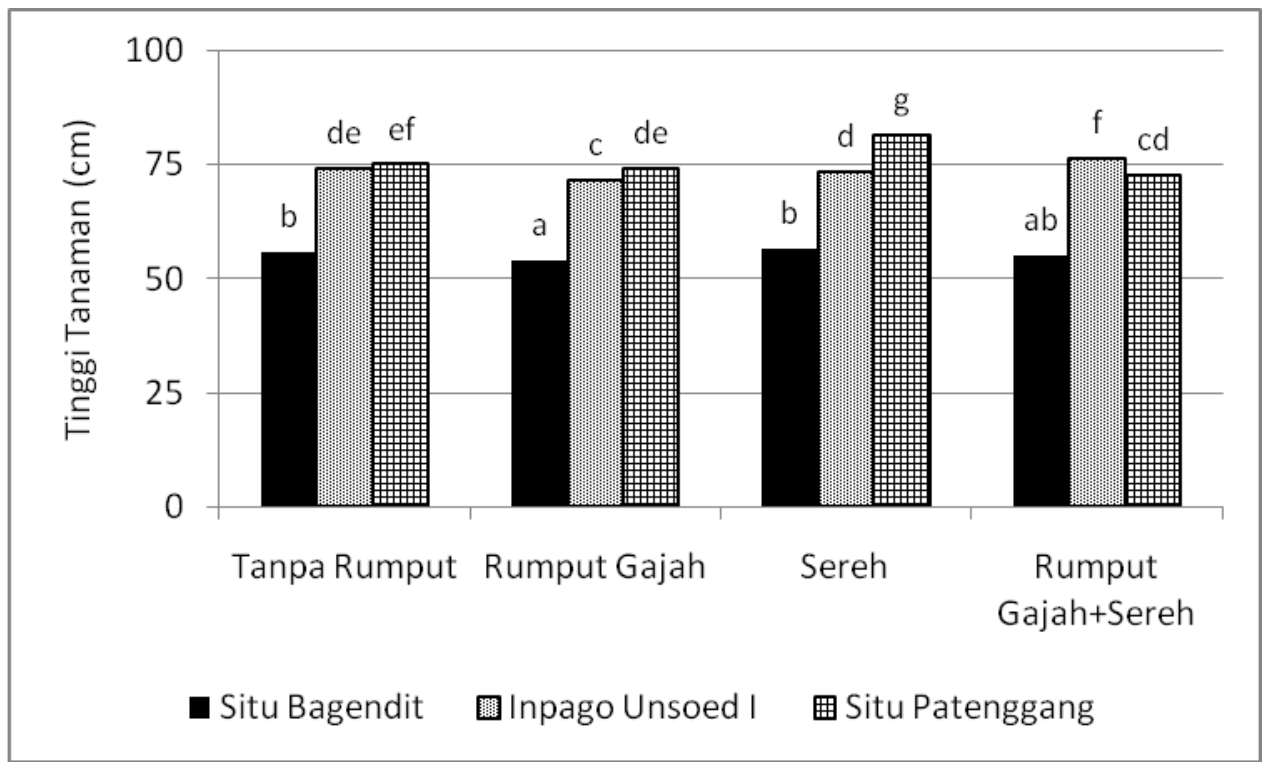

Gambar 1. Pengaruh tumpangsari padi-rumput terhadap tinggi tanaman pada berbagai varietas padi gogo.

Pada kondisi kekeringan, varietas Situ Patenggang memberikan respons terbaik saat ditanam tumpangsari padi-rumput dengan aplikasi asap cair tempurung kelapa terhadap jumlah gabah isi per rumpun (Gambar 2 \& 3), bobot gabah per petak efektif (Gambar 4) dan bobot gabah per hektar (Gambar 5).

Varietas Situ Patenggang mampu menghasilkan jumlah gabah per rumpun > 65 sedangkan untuk varietas Inpago Unsoed
1 dan Situ Bagendit hanya mampu menghasilkan $<25$ butir per rumpun.

Jumlah gabah per rumpun yang rendah berdampak pada bobot gabah per petak efektif maupun bobot gabah per hektar dengan hasil yang sangat rendah masingmasing $<50 \mathrm{~g}$ dan $<0,2 \mathrm{t} \mathrm{ha}^{-1}$. Meskipun varietas Situ Patenggang mampu menghasilkan bobot gabah 0,6-0,7 $\mathrm{t} \mathrm{ha}^{-1}$ (Gambar 5), dari potensi produksinya 4,6 t ha-1. 
Tabel 2. Pengaruh tumpangsari padi gogo - rumput dengan aplikasi asap cair tempurung kelapa pada berbagai varietas padi gogo terhadap luas daun $\left(\mathrm{cm}^{2}\right)$

\begin{tabular}{|c|c|c|c|c|c|}
\hline Varietas & ACTK & $\begin{array}{l}\text { Tanpa } \\
\text { Rumput }\end{array}$ & $\begin{array}{l}\text { Rumput } \\
\text { Gajah }\end{array}$ & Sereh & $\begin{array}{c}\text { Rumput } \\
\text { Gajah + Sereh }\end{array}$ \\
\hline \multirow{3}{*}{ Situ Bagendit } & 0 & $159,6 \mathrm{bcde}$ & $138,5 \mathrm{abcd}$ & $170,6 \mathrm{de}$ & 155,8 bcde \\
\hline & $1: 100$ & $162,9 \mathrm{cde}$ & $120,5 a b c$ & $244,7 f g$ & $133,7 \mathrm{abcd}$ \\
\hline & $1: 200$ & $104,8 a$ & $116,6 a b$ & $131,6 a b c$ & $152,1 \mathrm{bcd}$ \\
\hline \multirow{3}{*}{ Inpago Unsoed 1} & 0 & $313,4 \mathrm{jk}$ & 271,9ghij & $329,1 \mathrm{k}$ & $305,5 i j k$ \\
\hline & 1:100 & 303,8hijk & $263,3 \mathrm{ghi}$ & $327,3 k$ & $225,8 \mathrm{fg}$ \\
\hline & $1: 200$ & $325,7 \mathrm{k}$ & $254,6 \mathrm{~g}$ & 263,1ghi & $232,7 \mathrm{fg}$ \\
\hline \multirow{3}{*}{ Situ Patenggang } & 0 & $241,9 f g$ & $240,4 \mathrm{fg}$ & $258,7 \mathrm{gh}$ & $259,8 \mathrm{ghi}$ \\
\hline & 1:100 & $312,2 \mathrm{jk}$ & $230,3 \mathrm{fg}$ & $249,5 \mathrm{~g}$ & $249,7 \mathrm{~g}$ \\
\hline & $1: 200$ & $230,6 \mathrm{fg}$ & $242,9 f g$ & $241,5 f g$ & 201,2ef \\
\hline
\end{tabular}

Keterangan: $\quad$ ACTK= konsentrasi asap cair tempurung kelapa. Angka yang diikuti huruf yang sama antar kombinasi perlakuan menunjukan tidak berbeda nyata menurut uji LSD dengan $p=0.05$.

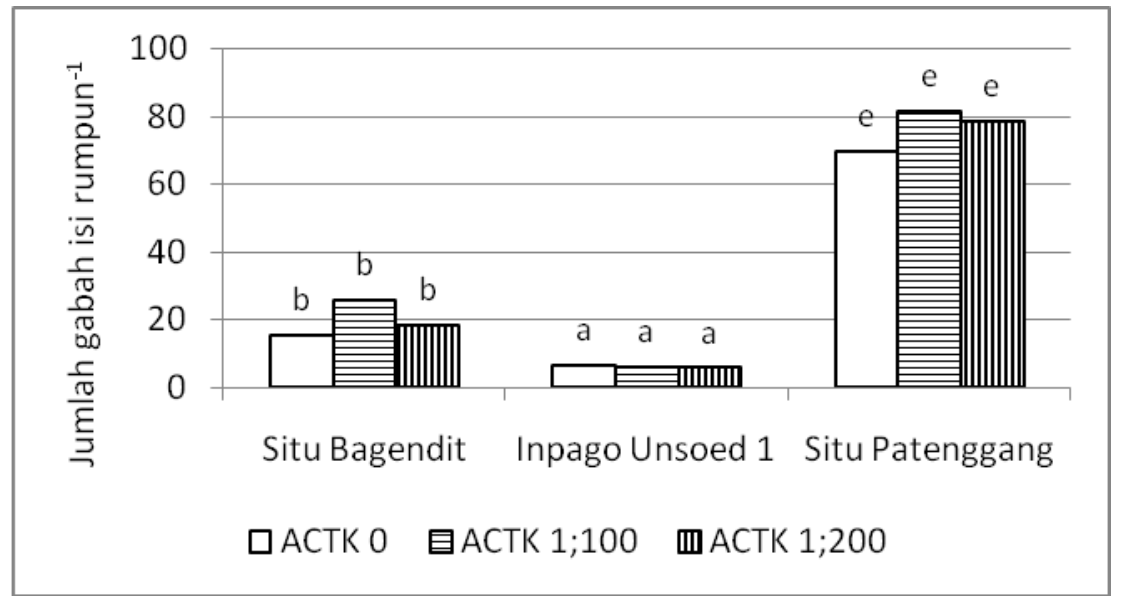

Gambar 2. Pengaruh aplikasi asap cair tempurung kelapa terhadap jumlah gabah isi per rumpun pada beberapa varietas padi gogo.

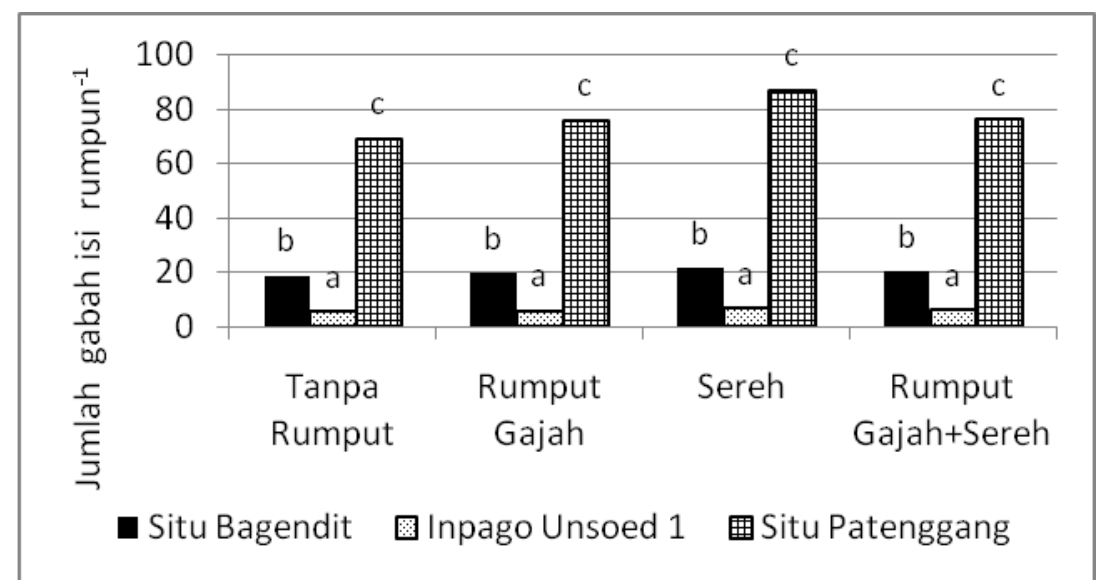

Gambar 3. Pengaruh tumpang sari padi-rumput pada beberapa varietas padi gogo terhadap jumlah gabah isi per rumpun. 


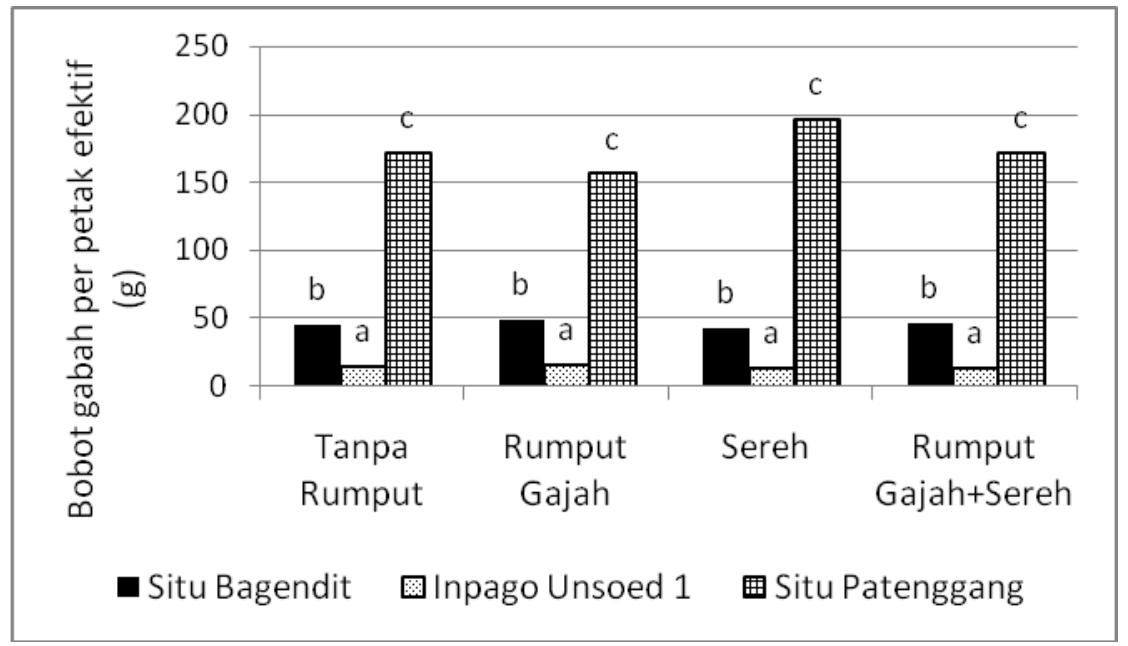

Gambar 4. Pengaruh tumpang sari padi-rumput pada beberapa varietas padi gogo terhadap bobot gabah per petak efektif $\left(3,75 \mathrm{~m}^{2}\right)$.

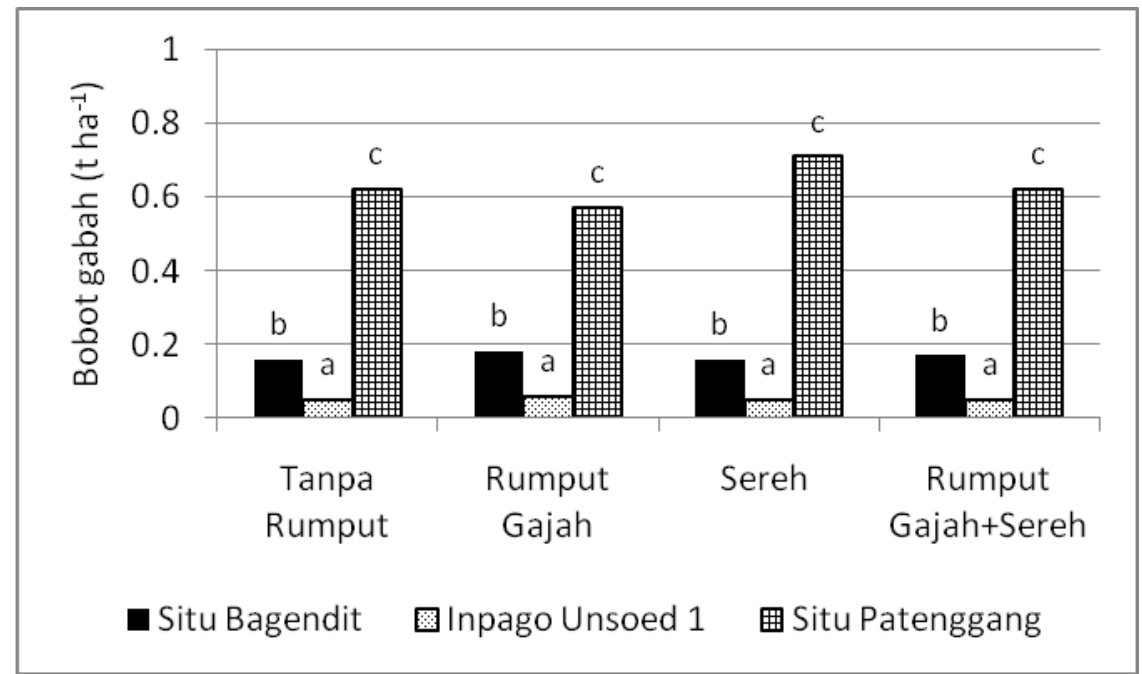

Gambar 5. Pengaruh tumpangsari padi-rumput pada beberapa varietas padi gogo terhadap bobot gabah per hektar.

Tabel 3 menunjukan bahwa indeks panen varietas padi gogo Situ Bagendit dan Inpago Unsoed 1 sangat rendah dibandingkan dengan varietas Situ Patenggang. Secara umum indeks panen yang dihasilkan oleh varietas Situ Bagendit dan Inpago Unsoed $1<0,30$ sedangkan varietas Situ Patenggan $>0,35$.
Intensitas serangan penggerek batang dan belalang relatif rendah $<2 \%$ pada semua varietas yang ditanam tumpangsari padi-rumput dengan aplikasi asap cair tempurung kelapa. Namun demikian, aplikasi asap cair tempurung kelapa 1:100 dan 1:200, dan tumpangsari padi dengan sereh menunjukan tingkat serangan yang rendah. 
Tabel 3. Indeks panen varietas padi gogo pada sistem tumpangsari rumput dengan aplikasi asap cair tempurung kelapa

\begin{tabular}{cccccc}
\hline \multirow{2}{*}{ Varietas } & ACTK & \multicolumn{4}{c}{ Tumpangsari padi-rumput } \\
\cline { 3 - 6 } & 0 & $\begin{array}{c}\text { Tanpa } \\
\text { Rumput }\end{array}$ & $\begin{array}{c}\text { Rumput } \\
\text { Gajah }\end{array}$ & Sereh & $\begin{array}{c}\text { Rumput Gajah }+ \\
\text { Sereh }\end{array}$ \\
\hline Situ & $0,20 \mathrm{~b}$ & $0,20 \mathrm{~b}$ & $0,23 \mathrm{c}$ & $0,18 \mathrm{~b}$ \\
Bagendit & $1: 100$ & $0,30 \mathrm{~d}$ & $0,27 \mathrm{c}$ & $0,34 \mathrm{e}$ & $0,29 \mathrm{~d}$ \\
& $1: 200$ & $0,24 \mathrm{c}$ & $0,25 \mathrm{c}$ & $0,25 \mathrm{c}$ & $0,24 \mathrm{c}$ \\
\hline \multirow{2}{*}{ Inpago } & 0 & $0,13 \mathrm{a}$ & $0,12 \mathrm{a}$ & $0,14 \mathrm{a}$ & $0,11 \mathrm{a}$ \\
Unsoed 1 & $1: 100$ & $0,17 \mathrm{~b}$ & $0,17 \mathrm{~b}$ & $0,18 \mathrm{~b}$ & $0,17 \mathrm{~b}$ \\
& $1: 200$ & $0,16 \mathrm{a}$ & $0,16 \mathrm{a}$ & $0,16 \mathrm{a}$ & $0,15 \mathrm{a}$ \\
\hline \multirow{2}{*}{ Situ } & 0 & $0,36 \mathrm{e}$ & $0,36 \mathrm{e}$ & $0,41 \mathrm{f}$ & $0,36 \mathrm{e}$ \\
Patenggang & $1: 100$ & $0,54 \mathrm{~g}$ & $0,54 \mathrm{~g}$ & $0,64 \mathrm{~h}$ & $0,52 \mathrm{~g}$ \\
& $1: 200$ & $0,45 \mathrm{f}$ & $0,44 \mathrm{f}$ & $0,50 \mathrm{~g}$ & $0,41 \mathrm{f}$ \\
\hline
\end{tabular}

Keterangan: $A C T K=$ konsentrasi asap cair tempurung kelapa. Angka yang diikuti huruf yang sama menunjukan tidak berbeda nyata menurut uji LSD $(p=0,05)$.

Penyakit hawar daun menunjukan tingkat infeksi yang rendah pada varietas Situ Bagendit dan Inpago Unsoed 1.
Aplikasi asap cair tempurung kelapa 1:100 dan tumpang sari padi dengan rumput gajah+sereh (Tabel 4).

Tabel 4. Intensitas serangan hama dan patogen pada perlakuan varietas padi gogo, aplikasi asap cair tempurung kelapa dan tumpangsari rumput

Perlakuan

\begin{tabular}{|c|c|c|c|c|}
\hline \multirow[t]{2}{*}{ Perlakuan } & \multicolumn{4}{|c|}{ Intensitas Serangan } \\
\hline & PB (\%) & Bel (\%) & $\mathrm{HD}(\%)$ & $\mathrm{BD}(\%)$ \\
\hline \multicolumn{5}{|l|}{ Varietas } \\
\hline Situ Bagendit & 3,10 & $2,69 b$ & $12,47 a$ & 23,51 \\
\hline Inpago Unsoed I & 3,06 & $2,33 a$ & $12,23 a$ & 24,14 \\
\hline Situ Patenggang & 3,26 & $2,38 a$ & $13,08 b$ & 24,19 \\
\hline KK (\%) & 19,69 & 17,51 & 11,58 & 6,81 \\
\hline \multicolumn{5}{|c|}{ Konsentrasi Asap Cair Tempurung Kelapa } \\
\hline 0 (Tanpa Aplikasi) & 3,30 & $2,92 b$ & $12,69 b$ & 24,54 \\
\hline $1: 100$ & 3,06 & $2,18 \mathrm{a}$ & $12,13 a$ & 23,52 \\
\hline $1: 200$ & 3,06 & $2,31 a$ & $12,56 b$ & 23,76 \\
\hline KK (\%) & 24,52 & 22,23 & 7,47 & 10,78 \\
\hline \multicolumn{5}{|l|}{ Tumpangsari padi-rumput } \\
\hline Tanpa Rumput & 3,25 & $2,53 b$ & $12,21 a$ & 23,22 \\
\hline Rumput Gajah & 3,26 & $2,82 \mathrm{c}$ & $12,43 b$ & 24,14 \\
\hline Sereh & 3,05 & $1,93 a$ & $12,59 b$ & 23,98 \\
\hline Rumput Gajah +Sereh & 2,99 & $2,59 b$ & $12,82 \mathrm{c}$ & 24,42 \\
\hline KK (\%) & 19,52 & 23,35 & 8,75 & 7,13 \\
\hline
\end{tabular}


Meskipun demikian, secara umum tingkat infeksi penyakit hawar daun rendah $<15 \%$. Penyakit bercakdaun menunjukan hasil yang tidak berbeda nyata antar varietas, aplikasi asap cair tempurung kelapa dan tumpangsari padi-rumput. Namun demikian, tingkat infeksi bercak daun cukup tinggi hampir 25\% (Tabel 4).

Serangan hama walang sangit sangat tinggi ( $>60 \%$ ) pada varietas padi gogo yang ditanam tumpangsari padi-rumput dengan aplikasi asap cair tempurung kelapa.
Varietas Situ Patenggang yang ditanam dengan sereh, diberi asap cair tempurung kelapa 1:100 dan 1:200 serta varietas Situ Bagendit yang diberi asap cair tempurung kelapa 1:100 menunjukan tingkat serangan yang lebih rendah $(<50 \%)$ dibandingkan dengan perlakuan lainnya. Inpago Unsoed 1 menunjukan sensitifitas tinggi terhadap serangan walang sangit (>50\%) (Tabel 5).

Tabel 5. Intensitas kerusakan padi gogo akibat walang sangit (\%) pada sistem tumpangsari padi-rumput dengan aplikasi asap cair tempurung kelapa

\begin{tabular}{cccccc}
\hline \multirow{2}{*}{ Varietas } & ACTK & \multicolumn{4}{c}{ Tumpangsari padi-rumput } \\
\cline { 3 - 6 } & & $\begin{array}{c}\text { Tanpa } \\
\text { Rumput }\end{array}$ & $\begin{array}{c}\text { Rumput } \\
\text { Gajah }\end{array}$ & Sereh & $\begin{array}{c}\text { Rumput Gajah }+ \\
\text { Sereh }\end{array}$ \\
\hline \multirow{2}{*}{ Situ } & 0 & $73,05 \mathrm{~h}$ & $70,39 \mathrm{~g}$ & $50,11 \mathrm{~b}$ & $63,43 \mathrm{e}$ \\
Bagendit & $1: 100$ & $61,76 \mathrm{e}$ & $65,72 \mathrm{f}$ & $46,07 \mathrm{a}$ & $58,64 \mathrm{~d}$ \\
& $1: 200$ & $65,79 \mathrm{f}$ & $69,09 \mathrm{~g}$ & $48,96 \mathrm{~b}$ & $60,43 \mathrm{~d}$ \\
\hline \multirow{2}{*}{ Inpago } & 0 & $76,56 \mathrm{i}$ & $79,04 \mathrm{j}$ & $63,33 \mathrm{e}$ & $76,47 \mathrm{i}$ \\
Unsoed 1 & $1: 100$ & $68,84 \mathrm{~g}$ & $75,33 \mathrm{i}$ & $53,07 \mathrm{c}$ & $72,52 \mathrm{~h}$ \\
& $1: 200$ & $73,38 \mathrm{~h}$ & $76,55 \mathrm{i}$ & $55,26 \mathrm{c}$ & $74,12 \mathrm{~h}$ \\
\hline \multirow{2}{*}{ Situ } & 0 & $73,01 \mathrm{~h}$ & $75,33 \mathrm{i}$ & $48,73 \mathrm{~b}$ & $68,36 \mathrm{~g}$ \\
Patenggang & $1: 100$ & $65,00 \mathrm{f}$ & $70,12 \mathrm{~g}$ & $43,96 \mathrm{a}$ & $65,83 \mathrm{f}$ \\
& $1: 200$ & $70,44 \mathrm{~g}$ & $73,24 \mathrm{~h}$ & $46,02 \mathrm{a}$ & $66,51 \mathrm{f}$ \\
\hline
\end{tabular}

Keterangan: $A C T K=$ konsentrasi asap cair tempurung kelapa. Angka yang diikuti huruf yang sama menunjukan tidak berbeda nyata menurut uji $\operatorname{LSD}(p=0,05)$.

Aplikasi asap cair tempurung kelapa konsentrasi 1:100 dan tumpangsari padi gogo-sereh mampu meningkatkan pertumbuhan tanaman padi gogo. Menurut Komaryati et al. (2011), komponen kimia asap cair seperti asam asetat dan metanol dapat berfungsi memacu pertumbuhan tanaman. Chumpookam et al. (2012) menyatakan bahwa aplikasi asap cair pada tanaman meningkatkan jumlah daun, kadar klorofil, dan kadar $\mathrm{N}$ di akar. Asap cair memiliki efek merangsang pertumbuhan, karena asap cair mengandung asam asetat yang berfungsi sebagai zat yang memicu pertumbuhan tanaman (Payamara, 2011; Muhakka et al., 2013) dan digunakan untuk merangsang pertumbuhan tanaman bawang (Kulkarni et al., 2010).

Pertumbuhan tanaman padi gogo pada tumpangsari padi gogo-sereh yang lebih baik menunjukkan bahwa keberadaan sereh tidak menyebabkan persaingan yang kuat yang dapat merugikan tanaman padi gogo dalam mendapatkan unsur hara dan air. Hasil penelitian Ahadiyat et al. (2013), 
meskipun keberadaan rumput belum mampu meningkat penampilan dari berbagai variabel pertumbuhan seperti tinggi tanaman, luas daun, jumlah daun, jumlah anakan, bobot tajuk, total panjang akar dan bobot kering akar, namun demikian keberadaan rumput tidak menjadikan kompetitor yang cukup berarti meskipun dalam kondisi kadar air tanah yang rendah (9-14\%).

Meningkatnya kadar klorofil b tanaman padi gogo pada tumpangsari padi gogorumput gajah+sereh diduga karena keberadaan rumput gajah+sereh menyebabkan cekaman cahaya rendah meskipun sudah dilakukan pemangkasan, sehingga kadar klorofil $b$ lebih tinggi. Menurut Zhang et al. (2016), indeks luas daun dan kadar klorofil b meningkat secara siginifikan pada kultivar Physocarpus sebagai respon terhadap intensitas cahaya rendah. Cahaya merupakan faktor ekologis penting yang memfasilitasi fotosintesis dan berpengaruh terhadap pertumbuhan, morfogenesis, serta kelangsungan hidup tanaman (Zhang et al., 2014).

Hasil penelitian Li dan Wang (2014) melaporkan bahwa, aplikasi asap cair dengan pengenceran lebih dari 50 kali mampu meningkatkan pertumbuhan dan hasil lada. Kulkarni et al. (2008) melaporkan, tanaman tomat yang diaplikasikan asap cair bertambah pertumbuhannya sampai tahap berbuah, kemudian berbuah lebih awal,dan jumlah buahnya meningkat. Beberapa penelitian lain menunjukkan bahwa, aplikasi asap cair mampu meningkatkan hasil kedelai (Pangnakorn et al., 2010), dan ubi jalar (Pangnakorn et al., 2013).

Tingginya intensitas serangan hama walang sangit (>50\%) menjadi faktor pendukung rendahnya hasil padi gogo yang diperoleh. Hal tersebut terjadi karena lahan penelitian merupakan satu-satunya lahan yang ditanami padi gogo, sehingga intensitas serangan walang sangitnya tinggi. Serangan walang sangit dapat menurunkan hasil 10-40\%, namun pada serangan yang berat akibat populasi yang tinggi dapat menurunkan hasil sampai $100 \%$ atau puso (Balai Besar Penelitian Tanaman Padi, 2015).

Basri (2010), melaporkan bahwa asap cair digunakan untuk mengusir serangga, mempercepat pertumbuhan pada akar, batang, umbi, daun, bunga dan buah. Hasil penelitian Santoso (2015) menyatakan bahwa, formulasi asap cair sabut kelapa, memberikan pengaruh terbaik bagi batang tanaman padi dan hasil, dengan adanya senyawa fenol, asam palmitat, metiloleat, dan siklotetrakosana dapat juga bertindak sebagai anti bakteri dan mikrobia yang dapat dikategorikan sebagai insektisida nabati.

Menurunnya intensitas serangan walang sangit tanaman padi gogo pada tumpangsari padi gogo-sereh mengindikasikan bahwa keberadaan sereh cukup mampu menekan serangan walang sangit mekipun tingkat serangannya masih tinggi $>30 \%$. Hal tersebut karena sereh mampu menghasilkan metabolit sekunder berupa sitronela dan flavonoid yang berperan sebagai biopestisida. Selain itu, pengelolaan secara dipangkas pada daun sereh untuk mengurangi kompetisi dalam mendapatkan cahaya dengan tanaman padi gogo, diduga meningkatkan aktivitas metabolit sekunder dari tanaman sereh yang mampu menekan serangan walang sangit.

Menurut Sudjak (2016), sereh wangi mempunyai mekanisme pengendalian anti serangga, insektisida, antifedan, repelen, 
antijamur, dan antibakteri. Bagian tanaman yang berpotensi mengendalikan hama adalah daun dan minyak atsirinya. Senyawa sitronela mempunyai sifat racun dehidrasi (desiccant) dan racun kontak. Serangga yang terkena racun ini akan mati karena kekurangan cairan. Selain itu, daun serai juga bersifat penolak (repellent) serta sebagai insektisida, bakterisida, dan nematisida. Prakash et al. (2008) melaporkan bahwa minyak atsiri dan flavonoid merupakan senyawa metabolit sekunder sebagai komponen utama biopestisida berbahan empon-empon yang berfungsi untuk mengusir hama, seperti walang sangit.

Secara umum, pada kondisi curah hujan rendah dan kondisi tanaman mengalami cekaman kekeringan, tanaman padi gogo belum mampu menghasilkan pertumbuhan yang optimal pada tumpangsari padi gogorumput dengan aplikasi asap cair tempurung kelapa. Aplikasi asap cair tempurung kelapa dan tumpangsari padi gogo-rumput hanya mampu memperoleh hasil < $1 \mathrm{t} \mathrm{ha}{ }^{-1}$. Meskipun demikian, penelitian ini mampu memberikan gambaran bahwa terdapat potensi dalam upaya meningkatkan pertumbuhan dan hasil padi gogo apabila ditanam secara tumpangsari dengan sereh dan diberi asap cair tempurung kelapa. Padi gogo varietas Situ Patenggang menunjukan potensi lebih baik dibandingkan dengan Situ Bagendit dan Inpago Unsoed 1. Potensi ini bisa didapat apabila penanaman padi gogo dilakukan saat curah hujan yang cukup sehingga tanaman tidak mengalami cekaman kekeringan. Selain sistem tumpangsari padi-rumput dengan aplikasi asap cair tempurung kelapa, pengendalian hama walang sangit perlu mendapatkan perhatian yang serius karena hama ini sebagai salah satu penyebab rendahnya hasil tanaman padi gogo.

\section{SIMPULAN}

1. Varietas Situ Patenggang menghasilkan pertumbuhan, fisiologis dan komponen hasil lebih tinggi dibandingkan Situ Bagendit dan Inpago Unsoed 1 namun rentan penyakit hawar daun.

2. Aplikasi asap cair tempurung kelapa belum mampu meningkatkan hasil padi gogo, namun pada konsentrasi 1:100 mampu meningkatkan pertumbuhan dan menurunkan intensitas serangan belalang, walang sangit dan hawar daun.

3. Keberadaan sereh pada tumpangsari padi gogo-sereh mampu menghasilkan pertumbuhan dan komponen hasil lebih tinggi serta mampu menurunkan intensitas serangan walang sangit dan belalang.

\section{UCAPAN TERIMA KASIH}

Penulis mengucapkan terima kasih kepada pihak Unsoed melalui LPPM dengan memberikan dana BLU UNSOED hibah Riset Unggulan TA 2016 sehingga bisa menghasilkan karya tulis ini.

\section{DAFTAR PUSTAKA}

Abdurachman, A., Dariah, A. \& Mulyani, A. (2008). Strategi dan teknologi pengelolaan lahan kering mendukung pengadaan pangan nasional. J. Litbang Pertanian, 27, 4349.

Ahadiyat, Y.R., Harjoso, T. \& Ismangil. (2013). Sistem intercrops pertanaman padi gogo-rumput terhadap pertumbuhan dan hasil padi gogo. Bionatura, 15, 126-131. 
Ahadiyat, Y.R., Harjoso, T. \& Indarjanto, B.S. (2015). Karakter morfologi dan hasil padi gogo yang ditanam pada lahan yang ditanami rumput. Agrovigor, 8, 9-17.

Badan Pusat Statistik. 2016. Statistik Pertanian. http://www.bps.go.id [19 Januari 2017].

Balai Besar Penelitian Tanaman Padi. 2015. Hama walang sangit dan cara pengendaliannya.

http://bbpadi.litbang.pertanian.go.id [20 April 2017].

Basri, A.B. (2010). Manfaat asap cair untuk tanaman. Seri Inovasi Pembangunan. Balai Pengkajian Teknologi Pertanian Aceh. Serambi Pertanian, 4, 1-2.

Chumpookam, J., Huey-Ling, L. \& ChingChang, S. (2012). Effect of smoke water on seed germination and seedling growth of papaya (Carica papaya cv. Tainung No.2). Hort. Sci., 47, 741-744.

Komarayati, S., Gusmailina \& Pari, G. (2011). Produksi cuka kayu hasil modifikasi tungku arang terpadu. J. Penelitian Hasil Hutan, 29, 234-247.

Kulkarni, M.G., Ascough, G.D. \& J. Van Staden. (2008). Smoke-water and a smoke-isolated butenolide improve growth and yield of tomatoes under greenhouse conditions. Hort. Tech., $18,449-454$.

Kulkarni, M.G., Ascough, G.D., Verschaeve, L., Baeten K., Arruda, M.P. \& Van Staden, J. (2010). Effect of smokewater and a smoke-isolated butenolide on the growth and genotoxicity of commercial onion. Sci. Hort., 124, 434-439.

Li, Z. \& Wang X. (2014). Effect of wood vinegar on soil properties and plant growth. J. Plant Nut. Fert., 20, 510516.

Muhakka, A., Napoleon, \& Hidayatul I. (2013). Pengaruh pemberian asap cair terhadap pertumbuhan rumput raja (Pennisetum purpureophoides). Pastura, 3, 30-34.

Mulyani, A., \& Sarwani, M. (2013). Karakteristik dan Potensi Lahan Sub Optimal untuk Pengembangan Pertanian di Indonesia. Jurnal Sumberdaya Lahan, 7, 47-55.

Murtilaksono, K. \& Anwar, S. (2014). Potensi, kendala dan strategi pemanfaatan lahan kering dan kering masam untuk pertanian (padi, jagung, kedele), peternakan dan perkebunan dengan menggunakan teknologi tepat guna dan spesifik lokasi. Prosiding Seminar Nasional Lahan Suboptimal. Palembang 26-27 September 2014.

Nazirah, L., \& Damanik, B.S.J. (2015). Pertumbuhan dan hasil tiga varietas padi gogo pada perlakuan pemupukan. J. Floratek, 10, 54-60.

Pangnakorn, U., Watanasorn, S., Kuntha, C. \& Chuenchooklin, S. (2010). Effects of wood vinegar and fermented liquid organic fertilizer on soybean (Srisamrong 1) in the drought season cultivation. J. ISSAAS, 16, 67-73.

Pangnakorn, U., Tayamanont, P. \& Kurubunjerdjit, R. (2013). Sweet potato organic cultivation with wood vinegar, entomopathogenic nematode and fermented organic substance from plants. Int. J. Nut. Food Engin., 7, 854-858.

Payamara, J. (2011). Usage of wood vinegar as new organic substance .Int. J. Chem. Tech. Res., 3, 16581662. 
Prakash, A., Rao, J. \& Nandagopal, V. (2008). Future of botanical pesticides in rice, wheat, pulses, and vegetables pest management. J. Biopes., 1, 154169.

Prasetyo, E., Sukardjo, I. \& Pujiwati, H. (2009). Produktivitas lahan dan NKL pada tumpang sari jarak pagar dengan tanaman pangan. J. Akta Agrosia, 12, 51-55.

Pusat Data \& Informasi Pertanian. (2017). Statistik Lahan Pertanian 2012-2016. Sekretaris Jenderal Kementerian Pertanian.

Santoso, R.S. 2015. Asap cair sabut kelapa sebagai repelan bagi hama padi walang sangit (Leptocorisa oratorius). J. Sainsmat, 4, 81-86.

Sudjak, M.S. (2016). Tumbuhan Indonesia potensial sebagai insektisida nabati untuk mengendalikan hama kumbang bubuk jagung (Sitophilus spp.). J. Litbang Pertanian, 35, 131142.
Sundari, T., Nugrahaeni, N. \& Susanto, W.A. (2016). Interaksi genotipe $x$ lingkungan dan stabilitas hasil biji kedelai toleran naungan. J. Agron. Indonesia, 44, 16-25.

Wahla, I.H., Ahmad, R., Ehsanullah, Ahmad, A. \& Jabbar, A. (2009). Competitive functions of component crops in some barley based intercropping systems. Int. J. Agric. Biol., 11, 6972.

Zhang, H., Zhong, H., Wang, J.I., Sui, X. \& Xu N. (2016). Adaptive changes in chlorophyll content and photosynthetic features to low light in Physocarpus amurensis Maxim and Physocarpus opulifolius "Diabolo". Peer J., 4, 1-23.

Zhang, Y., Xia, G.H., Ma, K., Li,G.Y., Dai, Y.C. \& Yan, C.X. (2014). Effects of shade on photosynthetic characteristics and chlorophyll fluorescence of Ardisia violacea. Chinese J. Applied Ecology, 25, 1940-1948. 